\title{
WEZWANIE DO PATRIOTYZMU WG ŚW. JANA PAWŁA ll
}

Streszczenie. W związku z 100. rocznicą odzyskania przez Polskę Niepodległości oraz 40. rocznicą wyboru kard. Karola Wojtyły na Stolicę św. Piotra autor niniejszego artykułu podejmuje refleksję nad nauczaniem św. Jana Pawła II. Autor ukazuje treść homilii, przemówień, rozważań i listów św. Jana Pawła II, których przesłanie pozwala kształtować w sobie właściwe postawy inspirowane jego osobą. Słowo, ale również postawa papieża Polaka, przedstawione w tym opracowaniu mogą być zaproszeniem do praktykowania postawy patriotyzmu.

Słowa klucze: św. Jan Paweł II; patriotyzm; Polska; niepodległość; ziemia ojczysta.

Abstract. A call to patriotism according to Saint Pope John Paul II. In connection with the 100th anniversary of Poland's regaining of the Independence and the 40th anniversary of the election of Cardinal Karol Wojtyla to the Holy See Piotr, the author of this article, reflects on the teaching of St. John Paul II. The author shows the content of the homilies, the speeches, the considerations and the letters of St. John Paul II,

* Ks. mgr lic. Jakub Nagi - od 2013 roku kapłan Diecezji Rzeszowskiej, absolwent Uniwersytetu Papieskiego Jana Pawła II w Krakowie, obecnie doktorant na Wydziale Teologicznym Uniwersytetu Mikołaja Kopernika w Toruniu i student dziennikarstwa i komunikacji społecznej w Wyższej Szkole Kultury Społecznej i Medialnej w Toruniu. 
whose message allows us to shape the right attitudes inspired the Pope. St. John Paul II's words and his behavior which are presented in this study may be an invitation to practice the accurate attitude to the patriotism.

Key words: St. John Paul II; patriotism; Poland; independence; homeland.

W związku z 100. rocznicą odzyskania przez Polskę Niepodległości oraz 40. rocznicą wyboru kard. Karola Wojtyły na Stolicę św. Piotra warto podjąć refleksję nad nauczaniem św. Jana Pawła II. Autor pragnie ukazać treść homilii, przemówień, rozważań i listów św. Jana Pawła II, których lektura pozwoli kształtować w sobie właściwe postawy inspirowane jego osobą. Słowo, ale również postawa papieża Polaka, przedstawione poniżej mogą być zaproszeniem do praktykowania postawy patriotyzmu.

Autor niniejszego artykułu w pierwszej części przedstawi najważniejsze pojęcia zawarte $\mathrm{w}$ temacie. Następnie ukaże przywiązanie Ojca Świętego do ziemi ojczystej. W trzeciej części zostaną przedstawione wskazania papieża dla swoich rodaków.

\section{POJĘClA}

Słownik współczesnego języka polskiego krótko definiuje słowo „wezwanie”. Według redakcji wezwanie to zwrócenie się do kogoś z apelem o coś1. Drugie istotne słowo to „patriotyzm”. Według Słownika języka polskiego Doroszewskiego można się dowiedzieć, że patriotyzm to miłość ojczyzny, przywiązanie do swego narodu. I już w rozwinięciu definicji autor podaje przykład Henryka Sienkiewicza, u którego „w pewnych partiach powieści [chodzi o Potop] dochodzi do głosu naprawdę niekłamany patriotyzm pisarza"

W nawiązaniu do podjętego tematu, analizując słowa klucze autor zestawia oba pojęcia. W tym aspekcie wezwania i miłości ojczyzny autor przedstawi nauczanie św. Jana Pawła II, które dotyczy bezpośrednio miłości do ojczyzny i przywiązania do rodzimego polskiego narodu.

${ }^{1}$ Słownik wspótczesnego języka polskiego, red. B. Dunaj, t. 2, Warszawa 2001, s. 509.

2 Słownik języka polskiego, red. W. Doroszewski, t. 6, Warszawa 1964, s. 190. 


\section{PRZYWIĄZANIE OJCA ŚWIĘTEGO DO OJCZYSTEJ ZIEMI}

Nazajutrz po uroczystej inauguracji pontyfikatu, 23.10.1979 roku, Jan Paweł II udzielił audiencji Polakom, którzy byli obecni na uroczystościach poprzedniego dnia. W przemówieniu skierowanym do obecnych tam pielgrzymów, zwrócił się również do wszystkich Polaków. Podkreślił, że jest jednym z synów „naszej drogiej Ojczyzny” i wyraził głęboką więź z krajem, z którego został powołany na Stolicę Piotrową. Papież mówił: „Miłość Ojczyzny łączy nas i musi łączyć ponad wszelkie różnice. Nie ma ona nic wspólnego z ciasnym nacjonalizmem czy szowinizmem. Jest prawem ludzkiego serca. Jest miarą ludzkiej szlachetności - miarą wypróbowaną wielokrotnie w ciągu naszej niełatwej historii”. Następnie podkreślił, że niełatwo jest zrezygnować z powrotu do Ojczyny, do tych gór i dolin, rzek i jezior, do tych ludzi umiłowanych. Jednocześnie prosił, by to jego odejście, jeszcze bardziej połączyło więź papieża z rodakami ${ }^{3}$.

Papieżowi od pierwszych chwil pontyfikatu zależało na duchowym pięknie Polski i Polaków. Ojciec Święty zachęcał, by Polacy przeciwstawiali się wszystkiemu, co uwłacza godności ludzkiej, co poniża obyczaje zdrowego społeczeństwa, co zagraża egzystencji i dobru wspólnemu, co umniejsza udział w rozwoju ludzkości i narodów chrześcijańskich ${ }^{4}$.

Również w tym przemówieniu papież prosił: „A Wy, drodzy Rodacy, czy teraz, czy kiedykolwiek, gdy przyjmować będziecie błogosławieństwo papieża Jana Pawła II, przypomnijcie sobie, że wyszedł on spośród Was i że ma szczególne prawo do Waszych serc i Waszej modlitwy" ${ }^{5}$.

Już podczas pierwszej pielgrzymki Jana Pawła II do Polski, potem ten gest powtarzał przy kolejnych podróżach apostolskich, papież ucałował ziemię. To bardzo wymowna, pełna powagi postawa, kiedy namiestnik Chrystusa ściągał piuskę, klękał i całował ziemię. Sam o tym geście powiedział: „Ucałowałem ziemię polską, z której wyrosłem. Ziemię, z której wezwał mnie Bóg - niezbadanym wyrokiem swojej Opatrzności - na Stolicę Piotrową w Rzymie. Ziemię, do której przybywam dzisiaj, jako

3 Por. tenże, Audiencja dla Polaków, 23.10 .1978 r., w: Leksykon wypowiedzi Jana Pawła II do Polaków, red. Z. Wietrzak, Kraków 2006, s. 298-299.

4 Por. tamże.

5 Por. tamże s. 300. 
pielgrzym”. Ten prosty gest, był jak określano, egzorcyzmem nad polską ziemią, był błogosławieństwem udzielonym rodakom i wreszcie był pozdrowieniem ziemi, która wydała Kościołowi papieża ${ }^{6}$.

Ojciec Święty podkreślał, że w polską ziemię, ziemię ojczystą jest głęboko wrośnięty korzeniami swojego życia, swojego serca i swojego powołania. Również homilia z Mszy św. celebrowanej na ówczesnym placu Zwycięstwa w Warszawie 2.06.1979 roku przeniknięta była przywiązaniem do Polski. Papież wołał z przejęciem: „Ja, syn polskiej ziemi, a zarazem ja, Jan Paweł II, papież. Wołam z całej głębi tego tysiąclecia”.

Podczas tej samej pielgrzymki, Ojciec Święty na spotkaniu w Belwederze wyraził swoje mocne przywiązanie do Ojczyzny. Mówił: „Pozwólcie, Szanowni Panowie, że będę to dobro nadal uważał za moje dobro, że będę tak samo głęboko odczuwał mój udział w nim, jakbym nadal mieszkał na tej ziemi i był obywatelem tego Państwa”. I dalej Ojciec Święty mówił, że z wielką siłą będzie nadal odczuwał wszystko to, co mogłoby zagrażać, szkodzić i przynosić ujmę Polsce. I w tym przemówieniu również podkreślił, że jest synem tej samej Ojczyzny .

Świadectwem głębokiego patriotyzmu papieża Polaka są słowa wygłoszone w UNESCO 2.06.1980 roku, to w nich Jan Paweł II wyraził przekonanie, że istotne jest pielęgnowanie prawdy historycznej każdego narodu. To zakorzenienie w przeszłości, niejednokrotnie trudnej i bolesnej, pozwala z umocnieniem patrzeć w przyszłość. „Jestem synem narodu, który przetrwał najstraszliwsze doświadczenia dziejów, który wielokrotnie był przez sąsiadów skazywany na śmierć - a on pozostał przy życiu i pozostał sobą. Zachował własną tożsamość i zachował pośród rozbiorów i okupacji własną suwerenność jako naród - nie w oparciu o jakiekolwiek inne środki fizycznej potęgi, ale tylko w oparciu o własną kulturę, która okazała się w tym wypadku potęgą większą od tamtych potęg”.

${ }^{6}$ Por. tenże, Przemówienie powitalne na lotnisku Okęcie, 02.06 .1979 r., w: tenże, Dzieła zebrane, t. 9: Homilie i przemówienia z pielgrzymek - Europa - część 1, Kraków 2008, s. 23

7 Por. tenże, Homilia $w$ czasie Mszy Św. odprawionej na Placu Zwycięstwa, 02.06.1979r., w: tamże, s. 30-33.

8 Por. tenże, Przemówienie do przedstawicieli władz państwowych wygłoszone w Belwederze, 02.06.1979 r., w: tamże, s. 27-29. 
Papież również podkreślił, że w tworzeniu kultury, która jej jednym z elementów tożsamości narodowej, najbardziej suwerenny jest człowiek ${ }^{9}$.

\section{POLSKA NARODEM LUDZI WIARY}

Jan Paweł II w czasie pierwszej pielgrzymki do Ojczyzny, mówił jak nierozłączne jest powiązanie dziejów Polski z Chrystusem, z wiarą chrześcijańską. Podkreślił, że „człowieka [...] nie można do końca zrozumieć bez Chrystusa. A raczej: człowiek nie może sam siebie do końca zrozumieć bez Chrystusa”. Ojciec Święty zachęcał, że drogą tego związku z Chrystusem obywatele Ojczyzny powinni iść nadal. „Trzeba iść po śladach tego, czym (a raczej kim) na przestrzeni pokoleń był Chrystus dla synów i córek tej ziemi”. To zaproszenie jest skierowane nie tylko do ludzi mocno wierzących, ale także do tych, którzy są poza wspólnotą Kościoła, a nawet wątpiących, czy sprzeciwiających się Chrystusowi i Kościołowi ${ }^{10}$.

Dalej Ojciec Święty podkreślał, jak ważne są więzi pomiędzy ludźmi danego narodu. Refleksja nad tą rzeczywistością pozwala zrozumieć człowieka, który poprzez swoje życie, działanie, twórczość do tej wspólnoty należy. Jednak bycie uczniem Chrystusa jest tą wspólnotą, która jest najważniejszą dla rozwoju człowieka, i która pozwala na pełne zrozumienie prawdy, kim jest człowiek ${ }^{11}$.

Jan Paweł II w nawiązaniu do obecności Polski na arenie międzynarodowej i jej roli wobec innych państw i narodów powiedział, że „Europa potrzebuje Polski głęboko wierzącej i po chrześcijańsku kulturowo twórczej, świadomej swojej roli wyznaczonej przez Opatrzność". Papież zaznaczył, że Polska może i powinna służyć Europie, tym, co w niej najbardziej wartościowe, czyli przywiązaniem do wierności Ewangelii, do chrześcijańskich tradycji i bogatym doświadczeniem religijnym. Papież

9 Por. tenże, Przemówienie w siedzibie UNESCO, 02.06.1980 r., w: tenże, Dzieła zebrane, t. 10 - Homilie i przemówienia z pielgrzymek - Europa - część 2, Kraków 2008, s. 99-108.

10 Por. tenże, Homilia $w$ czasie Mszy Św. odprawionej na Placu Zwycięstwa, 02.06.1979 r., w: tenże, Dzieła zebrane, t. 9 - Homilie i przemówienia z pielgrzymek Europa - część 1, Kraków 2008, s. 30-33.

11 Por. tamże. 
świadomy wielu współczesności zachęcał, że by „znaleźć w sobie tyle siły, by nasz naród mógł skutecznie oprzeć się tym tendencjom [...], które proponują odejście od wartości duchowych na rzecz nieograniczonej konsumpcji czy też porzucenie tradycyjnych wartości religijnych i moralnych dla kultury laickiej i etycznego relatywizmu"12.

\section{ZAKORZENIENIE W PRZESZŁOŚCI I SPOGLĄDANIE W PRZYSZŁOŚĆ}

Z wyjątkowym przesłaniem do rodaków zwrócił się Jan Paweł II podczas pielgrzymki w 1983 roku. Ojciec Święty podkreślił, że ostatnie lata to dla Polski i jej mieszkańców czas wyjątkowo trudny. Zarazem jest to doświadczenie, które może przynieść wiele dobra dla Ojczyzny, ale również dla Europy i dla świata. Papież wyraził wdzięczność tym wszystkim, którzy od grudnia 1981 roku świadczą pomoc względem Polski na wielu płaszczyznach. Papież zachęcał: „Jednakże Naród nade wszystko musi żyć o własnych siłach i rozwijać się o własnych siłach. Sam musi odnosić to zwycięstwo, które Opatrzność Boża zadaje mu na tym etapie dziejów". Przypomniał również, że nie chodzi o zwycięstwo militarne, ale przede wszystkim o zwycięstwo natury moralnej. Tego rodzaju zwycięstwo świadczyć będzie o następującej odnowie. I również świadectwem tego będzie ład życia narodowego i państwowego, gdzie respektowane będą podstawowe prawa człowieka. Takie funkcjonowanie społeczeństwa pozwoli na wyjście z kryzysu, wewnętrznego rozbicia i poprowadzi ku jedności. Jan Paweł II wskazał, że drogą do tego jest porozumienie i dialog rządzących i rządzonych ${ }^{13}$.

Ojciec Święty podczas spotkania z młodzieżą na Westerplatte, 12.06.1987 roku dał Polakom ważną lekcję. Przypomniał bohaterskie działanie młodych Polaków, żołnierzy, pod dowództwem majora Henryka Sucharskiego, którzy z determinacją i odwagą walczyli w obronie Ojczyzny. Papież zachęcał, by przykład tak ofiarnej postawy był wyzwaniem dla

12 Por. tenże, Przemówienie do Biskupów Polskich podczas wizyty Ad limina, 14.02.1981 r., „L'Osservatore Romano” 9 (236) 2001, s. 43-47.

${ }_{13}$ Por. tenże, Homilia w czasie Mszy Św. odprawionej na Stadionie Dziesięciolecia, 17.06.1983 r., w: tenże, Dzieła zebrane, t. 9 - Homilie i przemówienia z pielgrzymek Europa - część 1, Kraków 2008, s. 190-196. 
kolejnych pokoleń Polaków, którzy bez wahania będą podejmować i pielęgnować tę postawę miłości do ojczystej ziemi. Następnie wypowiedział słowa, które dla zebranej wówczas młodzieży, ale również dla wszystkich rodaków stanowią źródło refleksji. „Każdy z was, młodzi przyjaciele, znajduje też w życiu jakieś swoje Westerplatte. Jakiś wymiar zadań, które musi podjąć i wypełnić. Jakąś słuszną sprawę, o którą nie można nie walczyć. Jakiś obowiązek, powinność, od której nie można się uchylić. Nie można zdezerterować”. Ojciec Święty podkreślił, że to, co cenne, co wartościowe, należy szanować i pielęgnować, by służyło nie tylko danemu człowiekowi, ale wszystkim wokół ${ }^{14}$.

Z wyjątkowym przesłaniem zwrócił się Ojciec Święty do przedstawicieli Instytutu Dziedzictwa Narodowego UNESCO. Audiencja odbyła się 1.07.2001 roku w Rzymie. W swoim przemówieniu Jan Paweł II oparł się na lekturze pism C. K. Norwida, do których wrócił i jego pragnieniem było podzielić się refleksją. Jak zaznaczył Papież, to właśnie teksty Norwida podtrzymywały nadzieję pokładaną w Bogu w okresie niesprawiedliwości i pogardy podczas okupacji niemieckiej. Twórczość Norwida pozwalała trwać przy prawdzie, godnie żyć i również wejść głębiej w prawdę bycia człowiekiem, chrześcijaninem, Europejczykiem i Polakiem ${ }^{15}$.

Jan Paweł II za Norwidem przypomniał, że Polacy nie będą dobrymi patriotami, jeśli wpierw nie będą pracowali na swoje człowieczeństwo. W pracy nad tą postawą istotne jest zakorzenienie w przeszłości, ale jednocześnie odważne spoglądanie w przyszłość, gdyż Ojczyzna, według Norwida, „znajduje się w nieskończonej Przyszłości”. Dalej Ojciec Święty mówił: „Ład narodu przychodzi spoza narodu, ostatecznie jest on z Boga, i dlatego tym, którzy tak dalekosiężnie, bo kapłańsko, kochają swój naród, nie grozi nacjonalizm”. Wreszcie Jan Paweł II mówił, zarazem zadając pytanie: „Ileż polskich spraw potoczyłoby się inaczej, gdyby Polacy odnaleźli w swoim sumieniu prawdę głoszoną przez Norwida, że Ojczyzna jest to zbiorowy obowiązek, który składa się w naturze rzeczy z dwóch:

14 Por. tenże, Homilia w czasie Liturgii Słowa skierowana do młodzieży zgromadzonej na Westerplatte, 12.06 .1987 r., w: tenże, Dzieła zebrane, t. 9 - Homilie i przemówienia z pielgrzymek - Europa - część 1, Kraków 2008, s. 373-378.

${ }_{15}$ Por. tenże, Przemówienie podczas audiencji dla przedstawicieli Instytutu Dziedzictwa Narodowego, 01.07.2001 r., „L'Osservatore Romano” 3 (201) 1998, s. 54-56. 
z obowiązującego Ojczyznę dla człowieka i zobowiązującego człowieka dla Ojczyzny"16.

Z okazji 60. rocznicy wybuchu Powstania Warszawskiego Jan Paweł II napisał list skierowany do Lecha Kaczyńskiego, ówczesnego Prezydenta Miasta Stołecznego Warszawy. To kolejna lekcja patriotyzmu dla Polaków. Papież w liście wyraził szacunek, jaki należy kierować wobec tych, którzy walczyli w Powstaniu. Wielki hołd należy się tym, co nie szczędzili krwi i własnego życia dla Ojczyzny. „Jak wiele musiało być miłości do Ojczyzny w sercach tych, którzy nie zważając na młody, często jeszcze dziecięcy wiek, na całe życie, które otwierało się przed nimi, szli na barykady w imię osobistej i wspólnej wolności”. Papież podkreślił, że wpatrywanie się w postaci bohaterów narodowych winno być nie tylko zaproszeniem do powrotu do zamierzchłej historii, ale zachętą do umiłowania Ojczyzny, które w chwilach trudnych, ale i w czasie pokoju pozwoli przedkładać dobro wspólne, nad sprawy osobiste ${ }^{17}$.

\section{MIŁOŚĆ WZGLĘDEM ZIEMI OJCZYSTEJ}

Papież Jan Paweł II, pielgrzymując do Ojczyzny, odwiedzał swoje rodzinne miasto, Wadowice. Będąc tam kilkakrotnie, dawał wyraz przywiązania do małej ojczyzny. Podkreślał, jak ważna jest więź z miejscem, z którego się wyrasta, w którym człowiek rozwija się, gdzie uczy się i dojrzewa. „Wiadomo, jak wiele dla rozwoju ludzkiej osobowości i charakteru znaczą pierwsze lata życia, lata dziecięce, a potem młodzieńcze"18. Ojciec Święty dał kolejną lekcję patriotyzmu, kiedy wspominał lata spędzone w swojej rodzinnej miejscowości. Jego zachwyt nad rzekami, górami, krajobrazem, a także wspomnienia wielu osób, pośród których żył i wzrastał, jest przykładem do ukochana swoich rodzinnych stron. Papież ze wzruszeniem odwiedzał kościół parafialny, w którym przyjął sakrament

${ }^{16}$ Por. tamże.

17 Por. tenże, List na 60. rocznice wybuchu Powstania Warszawskiego, 27.07.2004 r., w: tenże, Dzieła zebrane, t. 3 - Listy, Kraków 2007, s. 888-889.

${ }_{18}$ Por. tenże, Przemówienie do mieszkańców Wadowic, 07.06.1979 r., w: tenże, Dzieła zebrane, t. 9 - Homilie i przemówienia z pielgrzymek - Europa - część 1, Kraków 2008, s. 122-124. 
Chrztu Świętego, rozpoczynając swoją silną więź z Chrystusem. „Z czcią całuję też próg domu Bożego - wadowickiej fary, a w niej chrzcielnicę, przy której zostałem wszczepiony w Chrystusa i przyjęty do wspólnoty Kościoła. W tej świątyni przystąpiłem do pierwszej spowiedzi i komunii świętej. Tu byłem ministrantem. Tu dziękowałem Bogu za dar kapłaństwa [...] Ile dobra, ile łask wyniosłem z tej świątyni i z tej parafialnej wspólnoty, wie jedynie Ten, który jest Dawcą wszelkich łask" ${ }^{19}$.

Patriotyzm to również przywiązanie do ziemi ojczystej, to troska o ziemię, która przez Boga została powierzona człowiekowi. Ojciec Święty w homilii podczas Mszy Świętej w Krośnie 10.06.1997 roku, w słowach pełnych szacunku i czci, zwrócił się do rolników i ludzi troszczących się o ziemię. Papież podkreślił, że miłość i przywiązanie do ziemi, jak pokazuje historia, okazywały się istotne w walce o przetrwanie. „Oddaję dziś hołd spracowanym rękom polskiego rolnika. Tym rękom, które z trudnej, ciężkiej ziemi wydobywały chleb dla kraju, a w chwilach zagrożenia były gotowe tej ziemi strzec i bronić”. Ojciec Święty prosił zebranych, by pozostali wierni tradycjom przodków, dla których ziemia i to, co ona wydaje, jest związane z dobrocią Boga i jego opatrznością. Ojciec Święty zachęcał, by szanować prastare polskie tradycje związane z kulturą wsi. To one, przekazywane z pokolenia na pokolenie, były nośnikiem polskiej tożsamości i wiary katolickiej. „Twórzcie kulturę wsi, w której obok nowych wymiarów, jakie niosą czasy, pozostanie - jak u dobrego gospodarza - miejsce na rzeczy dawne, uświęcone tradycją, potwierdzone przez prawdę wieków" 20 .

Z podobnym przesłaniem Ojciec Święty zwrócił się do rodaków podczas pielgrzymki w 1999 roku, kiedy wygłosił homilię w Zamościu 12 czerwca. Papież wyraził wdzięczność i szacunek wobec tych, którzy użyźniali ziemię, a w razie potrzeby bronili jej, nie szczędząc własnej krwi. Zwrócił się również do tych, którzy dzisiaj uprawiają ziemię, co Papież określił mianem „trudu służby ziemi”. Jan Paweł II, idąc za nauczaniem Kardynała Stefana Wyszyńskiego, a także inspirując się utworami Szymona Szymonowica, podkreślił wielkie znaczenie rolnictwo dla dobra narodu

19 Por. tenże, Homilia podczas Liturgii Słowa, 16.06.1999 r., w: tamże, s. 880-884.

20 Por. tenże, Homilia $w$ czasie Mszy Św. kanonizacyjnej bł. Jana z Dukli, 10.06.1997 r., w: tamże, s. 753-757. 
i państwa. „Wiem, że w dobie przemian społecznych i gospodarczych nie brak problemów, które często boleśnie nękają polską wieś. Trzeba, aby w procesie reform sprawy rolników były dostrzegane i rozwiązywane w duchu społecznej sprawiedliwości"21.

\section{TROSKA O FUNDAMENTALNE WARTOŚCI KSZTAŁTUJĄCE NARÓD}

Podczas pielgrzymki do Ojczyzny w 1997 roku Jan Paweł II w Legnicy poruszył temat życia społecznego. Zauważył, że w dobie dynamicznego rozwoju, nie można przejść obojętnie obok ludzi, którzy cierpią niedostatek. Niejednokrotnie są to osoby samotne, a także rodziny wielodzietne. Papież powiedział, że obowiązkiem wszystkich, a szczególnie sprawujących władzę, jest takie kierowanie gospodarką kraju, ustanawianie takiego prawa, i zarządzanie dobrem wspólnym, by nieść pomoc potrzebującym. "Jest to naszym wspólnym obowiązkiem, obowiązkiem miłości, nieść pomoc na miarę naszych sił tym, którzy jej oczekują." Ojciec Święty podkreślił, że wyrazem dbałości o Ojczyznę są inicjatywy na rzecz ubogich, bezdomnych, chorych. Wyrazem tego są rozwijające się dzieła charytatywne i wolontariat. Papież podziękował tym, „którzy na co dzień wykazują wrażliwość na potrzeby innych, umiejętność ofiarnego dzielenia się dobrami i wielkie zaangażowanie na rzecz drugiego człowieka”. Wreszcie papież zachęcił, by rozbudzać w sobie wrażliwość na wszelki niedostatek i ofiarnie działać w niesieniu nadziei, szczególnie tam, gdzie jej brakuje ${ }^{22}$.

Tematem, który dla Ojca Świętego był bardzo istotny, jest sprawa poszanowania życia ludzkiego. Papież, podczas kolejnych podróży apostolskich, wzywał swoich rodaków do podjęcia refleksji nad tym problemem. Ojciec Święty przypominał, że prawo do życia nie jest prawem dla wybranych i nie zależy od światopoglądu, czy religii. Jest uniwersalnym prawem człowieka. „Jest prawem najbardziej podstawowym [...] zasadą i normą kodeksu moralności, wpisanego w sumienie każdego człowieka”.

${ }^{21}$ Por. tenże, Homilia podczas Liturgii Słowa, 12.06.1999 r., w: tamże, s. 837-840.

${ }^{22}$ Por. tenże, Homilia $w$ czasie Mszy Św. odprawionej na dawnym radzieckim lotnisku wojskowym, 2.06.1997 r., w: tamże, s. 677-682. 
W homilii podczas Mszy Świętej przy Sanktuarium św. Józefa w Kaliszu, 04.06.1997., Papież podkreślił, że dla swojej Ojczyzny pragnie wspaniałej przyszłości. Zaznaczył, że należy uwrażliwić sumienia i podjąć wysiłek etyczny, by w całym narodzie życie ludzkie było chronione. „Dzisiaj świat stał się areną bitwy o życie. Trwa walka między cywilizacją życia a cywilizacją śmierci. Dlatego tak ważne jest budowanie kultury życia"23.

W trosce o piękno Ojczyzny i jej obywateli istotna jest kwestia wychowania. Papież, zwracając się do rodziców dzieci pierwszokomunijnych podczas spotkania z nimi powiedział, że prawo i obowiązek wychowania spoczywa na rodzicach. Prosił również, by tego zadania nie oddawać instytucjom, które, mimo iż przekazują odpowiednią wiedzę, nie dają autentycznego świadectwa wiary, świadectwa miłości i troski rodzicielskiej. Papież przestrzegał, by nie skupić się zbytnio na chęci zapewnienia dzieciom najlepszych warunków materialnych, kosztem poświęcenia im swojego czasu i uwagi, które w procesie wzrastania są niezbędne. Papież zachęcał: „Jeżeli chcecie [...] obronić wasze dzieci przed demoralizacją, przed duchową pustką, jakie proponuje świat przez różne środowiska, a nawet szkolne programy, otoczcie te dzieci ciepłem waszej rodzicielskiej miłości i dajcie im przykład chrześcijańskiego życia” ${ }^{24}$.

W rozwoju postawy patriotyzmu, który pozwala budować Ojczyznę na silnych wartościach, jest kierowanie się wzajemnym zaufaniem. Jan Paweł II w swoim nauczaniu podkreślał, że zaufanie winno opierać się na prawdzie. „Cały Naród Polski musi odzyskać to zaufanie w najszerszym kręgu swej społecznej egzystencji”. Papież uzależnił przyszłość Ojczyzny od zaufania, które ma być budowane na fundamencie, jakim jest prawda. Dążenie do takiej postawy jest procesem, w którym na każdym etapie istotne jest pragnienie pogłębiania zaufania. Wszystkie wymiary życia społecznego, politycznego, ekonomicznego i kulturalnego mają opierać się na elementarnym „wymiarze etycznym: prawda-zaufanie-wspólnota”. Papież podkreślał, że „tak jest w rodzinie. Tak jest też na inną skalę w narodzie i państwie. Tak jest wreszcie w całej rodzinie ludzkości”25.

${ }^{23}$ Por. tenże, Homilia w czasie Mszy Św. odprawionej przed Sanktuarium św. Józefa, 4.06.1997 r., w: tamże, s. 702-706.

${ }^{24}$ Por. tenże, Homilia w czasie Mszy Św. i konsekracji Kościoła Matki Bożej Fatimskiej, 07.06.1997 r., w: tamże, s. 722-725.

${ }_{25}$ Por. tenże, Homilia $w$ czasie Mszy Św., 21.06.1983r., w: tamże, s. 252-257. 
Ojciec Święty często podkreślał, że człowiek dojrzały, dobry obywatel to ten, który jest wolny, który odkrywa wolność daną mu, jako dar od Boga. Dlatego potrzeba wychowania człowieka do wolności, by była ona dojrzała, co pozwoli na właściwe funkcjonowanie społeczeństwa i narodu. „Nie można stwarzać fikcji wolności, która rzekomo człowieka wyzwala, a właściwie go zniewala i znieprawia”. Papież, mówiąc o wychowaniu do wolności, która wypływa z Dekalogu, wyraził jedność z rodakami, którzy w swojej historii niejednokrotnie doświadczali zniewolenia, tak fizycznego, jak również duchowego. Jan Paweł II, utożsamiając się z Ojczyzną i jej obywatelami, dał zachętę do praktykowania takiej postawy. Mówił: „Może, dlatego mówię tak, jak mówię, ponieważ to jest moja matka, ta ziemia! To jest moja matka, ta Ojczyzna! To są moi bracia i siostry! I zrozumcie, wy wszyscy, którzy lekkomyślnie podchodzicie do tych spraw, zrozumcie, że te sprawy nie mogą mnie nie obchodzić, nie mogą mnie nie boleć! Was też powinny boleć! Łatwo jest zniszczyć, trudniej odbudować. Zbyt długo niszczono! Trzeba intensywnie odbudowywać! Nie można dalej lekkomyślnie niszczyć!"26.

\section{PODSUMOWANIE}

Osoba św. Jana Pawła II, jego postawa i nauczanie, w omawianym temacie „wezwania do patriotyzmu” może być dla nas zachętą, by praktykować postawę miłości do ojczyzny. Nauczanie św. Jana Pawła II to wielki skarbiec, z którego każdy może czerpać wiele treści. Autor przedstawił wybrane fragmenty spuścizny Papieża Polaka. Mogą one być zaproszeniem do umiłowania Ojczyzny i do godnego jej reprezentowania w każdej sytuacji. Nauczanie Ojca Świętego może być również inspiracją do umiłowania tego, co polskie, rodzime i narodowe.

${ }^{26}$ Por. tenże, Homilia $w$ czasie Mszy Św. odprawionej na Lotnisku w Masłowie, 3.06.1991 r., w: tenże, Dzieła zebrane, t. 9 - Homilie i przemówienia z pielgrzymek - Europa - część 1, Kraków 2008, s. 474-478. 


\section{BIBLIOGRAFIA}

Jan Paweł II, Audiencja dla Polaków, 23.10 .1978 r., w: Leksykon wypowiedzi Jana Pawła II do Polaków, red. Z. Wietrzak, Kraków 2006, s. 298-299.

Jan Paweł II, Homilia podczas Liturgii Słowa, 12.06.1999 r., w: Jan Paweł II, Dzieła zebrane, t. 9: Homilie i przemówienia z pielgrzymek - Europa - część 1, Kraków 2008, s. 837-840.

Jan Paweł II, Homilia podczas Liturgii Słowa, 16.06.1999 r., w: Jan Paweł II, Dzieła zebrane, t. 9: Homilie i przemówienia z pielgrzymek - Europa, Kraków 2008, s. 880-884.

Jan Paweł II, Homilia w czasie Liturgii Słowa skierowana do młodzieży zgromadzonej na Westerplatte, 12.06.1987 r., w: tenże, Dzieła zebrane, t. 9: Homilie i przemówienia z pielgrzymek - Europa - część 1, Kraków 2008, s. 373-378.

Jan Paweł II, Homilia w czasie Mszy Św. i konsekracji Kościoła Matki Bożej Fatimskiej, 7.06.1997 r., w: tenże, Dzieła zebrane, t. 9: Homilie i przemówienia z pielgrzymek - Europa - część 1, Kraków 2008, s. 722-725.

Jan Paweł II, Homilia w czasie Mszy Św. kanonizacyjnej bł. Jana z Dukli, 10.06.1997 r., w: tenże, Dzieła zebrane, t. 9: Homilie i przemówienia z pielgrzymek - Europa część 1, Kraków 2008, s. 753-757.

Jan Paweł II, Homilia $w$ czasie Mszy Św. odprawionej na dawnym radzieckim lotnisku wojskowym, 2.06.1997r., w: tenże, Dzieła zebrane, t. 9 - Homilie i przemówienia z pielgrzymek - Europa - część 1, Kraków 2008, s. 677-682.

Jan Paweł II, Homilia w czasie Mszy Św. odprawionej na Lotnisku w Masłowie, 3.06 .1991 r., w: tenże, Dzieła zebrane, t. 9: Homilie i przemówienia z pielgrzymek - Europa część 1, Kraków 2008, s. 474-478.

Jan Paweł II, Homilia w czasie Mszy Św. odprawionej na Placu Zwycięstwa, 2.06.1979 r., w: tenże, Dzieła zebrane, t. 9: Homilie i przemówienia z pielgrzymek - Europa część 1, Kraków 2008, s. 30-33.

Jan Paweł II, Homilia w czasie Mszy Św. odprawionej na Stadionie Dziesięciolecia, 17.06.1983 r., w: tenże, Dzieła zebrane, t. 9: Homilie i przemówienia z pielgrzymek - Europa - część 1, Kraków 2008, s. 190-196.

Jan Paweł II, Homilia w czasie Mszy Św. odprawionej przed Sanktuarium św. Józefa, 4.06.1997 r., w: tenże, Dzieła zebrane, t. 9: Homilie i przemówienia z pielgrzymek - Europa - część 1, Kraków 2008, s. 702-706.

Jan Paweł II, Homilia w czasie Mszy Św., 21.06.1983r., w: tenże, Dzieła zebrane, t. 9: Homilie i przemówienia z pielgrzymek - Europa - część 1, Kraków 2008, s. 252-257.

Jan Paweł II, List na 60. rocznice wybuchu Powstania Warszawskiego, 27.07.2004 r., w: tenże, Dzieła zebrane, t. 3 - Listy, Kraków 2007, s. 888-889.

Jan Paweł II, Przemówienie do Biskupów Polskich podczas wizyty Ad limina, 14.02.1981r., „L'Osservatore Romano” 9 (236) 2001, s. 43-47.

Jan Paweł II, Przemówienie do mieszkańców Wadowic, 07.06.1979 r., w: tenże, Dzieła zebrane, t. 9: Homilie i przemówienia z pielgrzymek - Europa - część 1, Kraków 2008, s. $122-124$. 
Jan Paweł II, Przemówienie do przedstawicieli władz państwowych wygłoszone w Belwederze, 02.06.1979 r., w: tenże, Dzieła zebrane, t. 9: Homilie i przemówienia z pielgrzymek - Europa - część 1, Kraków 2008, s. 27-29.

Jan Paweł II, Przemówienie podczas audiencji dla przedstawicieli Instytutu Dziedzictwa Narodowego, 01.07.2001 r., „L'Osservatore Romano” 3 (201) 1998, s. 54-56.

Jan Paweł II, Przemówienie powitalne na lotnisku Okęcie, 02.06 .1979 r., w: tenże, Dzieła zebrane, t. 9: Homilie i przemówienia z pielgrzymek - Europa - część 1, Kraków 2008, s. 23.

Jan Paweł II, Przemówienie w siedzibie UNESCO, 02.06.1980 r., w: tenże, Dzieła zebrane, t. 10: Homilie i przemówienia z pielgrzymek - Europa - część 2, Kraków 2008, s. 99-108.

Słownik języka polskiego, red. W. Doroszewski, t. 6, Warszawa 1964.

Słownik współczesnego języka polskiego, red. B. Dunaj, t. 2, Warszawa 2001. 